\title{
Uloga prilagođene slikovnice u poticanju pripovijedanja
}

\author{
Monika Rosandić1, Sara Alviž², Jasmina Ivšac Pavliša ${ }^{3}$ \\ ${ }^{1}$ Edukacijsko-rehabilitacijski fakultet Sveučilišta u Zagrebu, Zagreb, Hrvatska \\ ${ }^{2}$ Centar za rehabilitaciju Stančić, Dugo Selo, Hrvatska \\ 3 Edukacijsko-rehabilitacijski fakultet Sveučilišta u Zagrebu, Zagreb, Hrvatska
}

Sažetak: Zajedničko čitanje slikovnica prirodna je aktivnost kojom se potiču vještine rane pismenosti, a prediktivno je i za kasnije vještine čitanja i pisanja. Zbog širokog raspona mogućnosti u obliku tehničkih, sadržajnih i jezičnih prilagodbi prilagođene slikovnice pružaju mogućnost interaktivnog sudjelovanja djeci s različitim odstupanjima od urednog komunikacijsko-jezično-govornog razvoja, a pozitivni učinci pojavljuju se i kod populacije urednog razvoja.

Cilj je ovog istraživanja bio ispitati uspješnost pripovijedanja nakon čitanja prilagođene slikovnice u odnosu na standardnu slikovnicu. Pripovjedne sposobnosti, promatrane na makrostrukturalnoj razini, ispitane su na uzorku od 30 djece kronološke dobi između 5;07 i 6;07 godina, urednog kognitivnog i jezičnog razvoja. Za potrebe istraživanja korištene su dvije priče, Mačka i Pas, koje su dio instrumenta MAIN - hrvatska inačica: Višejezični instrument za ispitivanje pripovijedanja.

Rezultati su pokazali kako se statistički značajne razlike pojavljuju u području razumijevanja sadržaja te uporabi riječi kojima se izražavaju unutarnja stanja likova. Nisu pronađene značajne razlike u cjelokupnoj strukturi priče i na većini razina strukturalne složenosti. Dobiveni rezultati upućuju na potrebu za daljnjim istraživanjima u ovom području kako bi se stvorili temelji za logopedsku praksu utemeljenu na dokazima.

Ključne riječi: prilagođena slikovnica, pripovjedne sposobnosti, složene komunikacijske potrebe, MAIN hrvatska inačica: Višejezični instrument za ispitivanje pripovijedanja

\section{Uvod}

\section{Pripovjedne sposobnosti}

Sposobnost djeteta da razumije i proizvede pripovjednu strukturu u predškolskom, nečitalačkom razdoblju, preduvjet je za razumijevanje pročitanoga teksta u čitalačkoj fazi. Pripovjedna sposobnost nalazi se među temeljnim vještinama rane pismenosti koje su pretpostavka za uredno ovladavanje vještinom čitanja i pisanja (Daly, Neugebauer, Chafouleas i Skinner, 2015). U pripovijedanju se isprepliću različite vještine kao što su primjerice nizanje događaja, uporaba specifičnog rječnika, oblikovanje povezanog teksta te razumijevanje uzročno-posljedične povezanosti. Stoga se 
pripovijedanje ujedno smatra jednom od pragmatičkih sposobnosti koja zahtijeva integraciju različitih kognitivnih, jezičnih i socijalnih vještina (Adams, 2002; Liles, Duffy, Merrit i Purcel, 1995). Očekuje se da djeca pred polazak u školu jezično dobro oblikuju priču koja pritom sadrži osnovnu strukturu, što je temelj za razumijevanje i proizvodnju složenijih oblika pripovjednog diskursa (Kuvač Kraljević i Olujić, 2015).

Istraživanja su pokazala da jezične mjere dobivene analizom pripovjednih uzoraka razlikuju djecu s obzirom na kronološku dob (Kuvač, 2004; Kelić, Hržica i Kuvač Kraljević, 2012) te da su dobar pokazatelj na temelju kojeg se zaključuje o postojanju jezičnih teškoća i/ili teškoća u čitanju (Kelić i sur., 2012; Peretić, Padovan i Kologranić Belić, 2015). U okviru logopedske intervencije jedan je od ciljeva rada s djecom s razvojnim jezičnim poremećajem upravo jačanje pripovjednih sposobnosti (Gillam i Gillam, 2016).

Pripovjedni uzorci prikupljaju se na način da se $u$ ispitnoj situaciji bilježe reakcije na neki elicitirajući materijal (Kuvač i Palmović, 2007). Pripovijedanje je, uz različite vrste prepričavanja, jedna od dostupnih elicitirajućih metoda u okviru koje ispitanik samostalno oblikuje priču povezujući strukturne elemente (Boerma, Leseman, Timmermeister, Wijnen i Blom, 2016). U istraživanjima se najčešće koristi pripovijedanje na temelju slikovnog materijala.

Analiza pripovjednog uzorka podrazumijeva analizu na globalnoj (makrorazini) i na mikrorazini. Makrorazina uključuje analizu strukture priče (događaji, problemi, inicijative likova da riješe probleme, reakcije likova) te strukturalnu složenost. Analiza na mikrorazini temelji se na raščlanjivanju riječi ili iskaza oslanjanjem na različite leksičke i sintaktičke mjere (pr. Norbury i Bishop, 2003). Sve navedeno objašnjava razloge zbog kojih se golem istraživački interes već desetljećima pridaje razvoju sposobnosti pripovijedanja, različitim razvojnim obilježjima vezanima uz pripovijedanje te razvoju intervencija usmjerenih na jačanje vještine pripovijedanja.

\section{Prilagodba slikovnica}

Slikovnice, kao atraktivan slikovni materijal koji se odnedavno sve češće obogaćuje različitim multimedijskim dodatcima, smatraju se alatom koji nudi različite mogućnosti za uvježbavanje pripovijedanja. Međutim, iako zajedničko čitanje priče može pružiti brojne prilike za upoznavanje strukture priče te susretanje s različitim jezičnim strukturama, kada priča sadržajem i strukturom nadilazi djetetovu kognitivnu i jezičnu razinu, takav sadržaj će za dijete biti neobradiv, a smisao teksta nedohvaćen (Dodd, 2012). Stoga je uvođenje prilagodbe tijekom čitanja prepoznato kao temeljna smjernica za poticanje djece koja se po svojim kognitivnim, komunikacijskim i/ ili jezičnim obilježjima razlikuju od vršnjaka. Sve su brojnija istraživanja usmjerena na utvrđivanje učinkovitosti različitih prilagodbi u kontekstu zajedničkog čitanja kod djece sa složenim komunikacijskim potrebama koja ne mogu ostvariti svoje komunikacijske potrebe uobičajenim načinom komuniciranja (Beukelman i Mirenda, 2013). Smatra se da su složene komunikacijske potrebe obilježje djece s poremećajem iz spektra autizma (PSA), djece $\mathrm{s}$ intelektualnim teškoćama, djece s motoričkim teškoćama i skupine s dječjom govornom apraksijom. Pozitivni učinci prilagodbe ponašanja odrasle osobe tijekom zajedničkog čitanja s djetetom potvrđeni su u djece s razvojnim jezičnim poremećajem (Crowe, Norris i Hoffman, 2004), u djece s poremećajem iz spektra autizma (Bellon, Ogletree i Harn, 2000) te u različitih korisnika potpomognute komunikacije (Liboiron i Soto, 2006). Neke od primijenjenih strategija podrške u navedenim istraživanjima odnose se na preinačava- 
Rosandić, M., Alviž, S., Ivšac Pavliša, J., Uloga prilagođene slikovnice u poticanju pripovijedanja Klinička psihologija 13 (2020), 1-2, 21-34

nje/elaborirano proširivanje djetetovih iskaza (eng. recast), ponavljajuće čitanje priče (eng. repeated storybook reading) i vođeno sudjelovanje (eng. scaffolding). Uz korištenje spomenutih strategija zabilježeno je poboljšanje u jezičnim mjerama poput povećanja ukupnog broja riječi, ukupnog broja različnica te komunikacijskim mjerama poput veće spontanosti u proizvodnji, većeg broja komunikacijskih izmjena i slično.

Osim prilagođenog ponašanja odrasle osobe koja sudjeluje u zajedničkom čitanju, prilagodbom slikovnica prema univerzalnom dizajnu za učenje (eng. Universal Design for Learning (UDL)), slikovnice je moguće učiniti dostupnima svim osobama s odstupanjima u komunikacijskom i jezičnom razvoju (CAST, 2011). Ovakva prilagodba slikovnica zahtijeva tehničku i sadržajnu prilagodbu. Tehničke prilagodbe odnose se na fizičke izmjene materijala za čitanje koje olakšavaju uporabu i manipuliranje slikovnicom. Primjerice, stranice slikovnice mogu se plastificirati kako bi bile jednostavnije za manipulaciju i održavanje, za osobe s motoričkim teškoćama može se dodati ručka za lakše otvaranje slikovnice, a za osobe s oštećenjima vida mogu se dodati vizualni ili taktilni elementi (Schoonover i Norton-Darr, 2016). Prilagodba sadržaja odnosi se na sadržajnu, strukturnu i lingvističku prilagodbu materijala. Sadržajna i strukturna prilagodba teksta izravno utječe na kognitivne sposobnosti čitatelja u smislu mogućnosti upamćivanja priče, povezivanja znanja o događajima te oslanjanja na kontekstualnu podršku. Ako se struktura ne može lako prepoznati ili je previše apstraktna, djeca sa složenim komunikacijskim potrebama mogu biti zbunjena. Stoga poznatost i predvidljivost strukture priče čini priču jednostavnijom za razumijevanje (Dodd, 2012).

Lingvističkoj složenosti standardnih priča nastoji se doskočiti sintaktičkim i semantičkim preinakama te hijerarhijskim postavljanjem pitanja (Franke i Dodd, 2009). Sintaktički se prvo uvode jednostavnije rečenice, a kasnije složene jer djetetu valja osigurati iskustvo s ciljanim rečeničnim obrascima kako bi shvatilo sadržaj priče. Iskustvo se stječe korištenjem repetitivnih i lako pamtljivih fraza dok se ciljana sintaktička struktura ne usvoji. Iz semantičke perspektive prilagodbe, odabire se rječnik koji je konkretan i jednostavno se može prikazati slikom, a potom se postupno podiže razina složenosti uvođenjem apstraktnijih koncepata poput emocija, namjera i želje (Dodd, 2012). Postavljanje pitanja započinje s vrlo jednostavnim “ovdje i sada” pitanjima (Tko? Što? Što radi? Da/Ne? Gdje?), a u kasnijim fazama uvode se pitanja koja traže zaključivanje (Zašto? Kako?) (Franke i Dodd, 2009).

Pisane su riječi djeci sa složenim komunikacijskim potrebama izrazito zahtjevne pa još jedan način prilagodbe predstavlja korištenje grafičkih simbola kao zamjene za riječ ili korištenje kombinacije grafičkog simbola i riječi. Grafički simboli odnose se na vizualnu reprezentaciju određenog koncepta te čine značenje pisane riječi lakšim za razumijevanje (Car, Ivšac Pavliša i Rašan, 2018).

U skladu s teorijom zone proksimalnog razvoja (Vygotsky, 1986), u kojoj se naglašava podudarnost oblika poticanja i stupnja djetetova razvoja, prilagodba se slikovnice može promatrati kao način na koji odrasla osoba određuje djetetovu razinu znanja i obrade te nudi potrebnu podršku kako bi dijete od trenutačne razine dostiglo višu razinu, odnosno sljedeći razvojni korak.

\section{Primjena prilagođenih slikovnica}

$U$ istraživačkim miljeima zamijećen je interes za ispitivanje učinkovitosti prilagođenih slikovnica u poticanju djece sa složenim komunikacijskim potrebama, posebno kod djece s intelektualnim teškoćama te poremećajem iz spektra autizma. 
Stephenson (2009) je pomoću prilagođene slikovnice ispitala razumijevanje receptivne i ekspresivne svrhe grafičkih simbola te vezu između grafičkih simbola i izgovorene riječi ili stvarnog predmeta kod djece s teškim intelektualnim teškoćama. Dio sudionika pokazao je poboljšanje u razumijevanju veze između grafičkog simbola, stvarnog predmeta i ilustracije u knjizi. Također, rezultati su pokazali kako je intervencija povećala interaktivno sudjelovanje u čitanju priča, što je bitno zbog stvaranja preduvjeta za razvoj vještina rane pismenosti. Slično su potvrdila i druga istraživanja s osobama s teškim intelektualnim teškoćama (Browder, Mims, Spooner, Ahlgrim-Delzell i Lee, 2008). Na temelju već spomenutog UDL okvira, osmišljen je intervencijski program zajedničkog čitanja prilagođenih slikovnica (Golloher, 2018) za djecu s poremećajem iz spektra autizma. Rezultati su pokazali da su svi ispitanici pokazali povećano sudjelovanje $\mathrm{u}$ aktivnostima koje potiču pismenost.

Osim s kliničkom populacijom, primjena prilagođenih slikovnica pronašla je mjesto i u istraživanjima s populacijom tipičnog razvoja. Trudeau, Cleave i Woelk (2003) ispitali su dobrobiti zajedničkog čitanja prilagođenih priča, između ostaloga, s dvoje djece urednog razvoja dobi oko četiri godine te su pokazali da su djeca nakon intervencije mogla povezati pisanu riječ u tekstu s nazivom grafičkog simbola. $\mathrm{Na}$ temelju rezultata autori naglašavaju potencijal za dodatno poticanje jezičnog razvoja čak i ako nema odstupanja u razvoju. $\mathrm{Na}$ tragu ovih rezultata, Thomas i Ross (2017) potvrđuju kako korištenje prilagođene slikovnice obogaćene nizom grafičkih simbola koje ispitivač pokazuje tijekom čitanja dovodi do poboljšanja razumijevanja priče te razumijevanja pitanja vezanih uz priču u djeteta predškolske dobi urednog razvoja, ali s ispodprosječnim predvještinama čitanja i pisanja.

U navedenim je istraživanjima korištena prilagodba slikovnice u obliku umetanja gra- fičkih simbola kojima je prilagođeni tekst popraćen, dok je u nekim istraživanjima svako dijete imalo i vlastitu komunikacijsku ploču s grafičkim crtežima (Stephenson, 2009; Trudeau i sur., 2003). Također, u neka su istraživanja uključene i različite komunikacijsko-čitalačke strategije (engl. communicative reading strategies), poput predviđanja sadržaja priče gledanjem ilustracija prije čitanja, pojašnjavanja i definiranja nepoznatih riječi, preusmjeravanja na priču nakon odgovora na komentar djeteta itd. (Thomas i Ross, 2017).

Može se zamijetiti kako je u svim spomenutim radovima u prilagođene slikovnice, $\mathrm{u}$ čije je izvorne neprilagođene oblike integrirana slikovna podrška za pisane tekstove, dodatno umetnuta vizualna podrška u obliku grafičkih simbola. Ovo se načelo naglašenog vizualnog modaliteta temelji na empirijskim dokazima koji upućuju na pozitivne učinke uvođenja dodatnog modaliteta za razvoj jezika. Primjerice, Cheetham (2017) objašnjava tzv. dodatni učinak (engl. additive effect) koji podrazumijeva s jedne strane preklapanje modaliteta, što dovodi do redundantnosti i time povećava vjerojatnost pravilne obrade, a s druge strane, informacije specifične za svaki modalitet, što u konačnici dovodi do povećanja cjelokupnog unosa informacija. To bi značilo da prikazivanje informacije ilustracijom i pisanim tekstom poboljšava razumijevanje i upamćivanje u odnosu na informaciju primljenu isključivo tekstualnim putem.

\section{Ciljevi i problemi istraživanja}

Primjer kombiniranja različitih modaliteta zorno odražavaju slikovnice koje omogućavaju složene vizualno-verbalne interakcije. Unatoč prethodno opisanim dobrobitima i činjenici da se prilagođene slikovnice često koriste $\mathrm{u}$ logopedskom radu, njihova primjena u logopedskom radu i njihova uloga nisu do- 
Rosandić, M., Alviž, S., Ivšac Pavliša, J., Uloga prilagođene slikovnice u poticanju pripovijedanja Klinička psihologija 13 (2020), 1-2, 21-34

voljno istraženi. U istraživačkim krugovima u Hrvatskoj na ovu temu nije pronađen nijedan objavljen rad. Stoga je cilj ovoga istraživanja utvrditi uspješnost pripovijedanja nakon čitanja prilagođene slikovnice u odnosu na standardne slikovnice kod djece predškolske dobi urednog razvoja. Pripovjedna sposobnost kao pragmatička vještina u ovom je radu analizirana na makrostrukturalnoj razini. S obzirom na definirani cilj, postavljene su pretpostavke da će nakon čitanja prilagođene slikovnice, $\mathrm{u}$ odnosu na standardnu slikovnicu, priča koju će ispitanik osmisliti imati sljedeća obilježja:

a) priča će sadržavati više strukturalnih elemenata;

b) strukturalna složenost priče bit će veća;

c) priča će uključivati više riječi za izražavanje unutarnjih stanja;

d) ispitanik će bolje razumjeti priču.

\section{Metode}

\section{Uzorak sudionika}

$\mathrm{U}$ istraživanju je sudjelovalo ukupno 30 djece kronološke dobi između 5;07 i 6;07 godina. Među djecom bilo je 16 djevojčica i 14 dječaka. Svi ispitanici uključeni su u redovan vrtićki program. Od stručnog suradnika logopeda dobiveni su podatci o urednom intelektualnom, motoričkom ili senzoričkom te jezičnom razvoju. U istraživanju su sudjelovala samo djeca čiji su roditelji prethodno potpisali informirani pristanak.

\section{Mjerni instrument}

Za potrebe istraživanja korišten je MAIN - hrvatska inačica: Višejezični instrument za ispitivanje pripovijedanja (Hržica i Kuvač Kraljević, 2012; Gagarina i sur., 2012). MAIN je dio LITMUS (eng. Language Impairment Te- sting in Multilingual Settings) baterije testova (Gagarina i sur., 2012), a osmišljen je kao instrument za procjenu pripovjednih vještina djece u dobi od tri do 10 godina koja usvajaju jedan ili više jezika od rođenja do rane dobi. Iako nije normiran, zbog ujednačenosti, kontroliranosti te standardne procedure može se koristiti kao istraživački instrument. Njime se ispituje razumijevanje i proizvodnja priče. Materijal se sastoji od četiri usporedne priče koje su kontrolirane s obzirom na kognitivnu i lingvističku složenost, usporednost u makrostrukturi i mikrostrukturi te kulturološku prikladnost i robusnost.

S obzirom na ciljeve istraživanja odabrane su dvije priče, a kao elicitirajuća metoda odabrano je prepričavanje uz korištenje slika nakon čitanja (engl. retelling). Navedene priče koristile su se u dva oblika, standardnom i prilagođenom. Za analizu strukture priče korišten je model gramatike priče (eng. story grammar) koji su predstavile Stein i Glenn 1979. (Cannizzaro i Coelho, 2013), no u prilagođenoj inačici koja se inače koristi u instrumentu MAIN. Prema tom modelu, svaka priča počinje davanjem informacija o vremenu i mjestu radnje kao ključnih dijelova situacije. Potom slijede tri pripovjedne epizode, od kojih svaku sačinjava unutarnje stanje lika koje inicira događaje, potom cilj, pokušaj ostvarivanja cilja, ishod pokušaja te na kraju unutarnje stanje kao reakcija lika na ishod epizode.

Standardna slikovnica sastoji se od niza od šest slika koje su posložene u obliku harmonike, tako da se prvo vide dvije slike, pa četiri i na kraju svih šest slika. Prilagođena slikovnica sadrži tehničke prilagodbe u obliku plastificiranja stranica i postavljanja čičak trake s grafičkim simbolima ispod slika. Grafički simboli izrađeni su u programu Picto-selector pomoću simbola preuzetih iz galerija ARAASAC, Mulberry Symbols i Sclera Pictos, a ispod njih je ispisan standardni tekst instrumenta MAIN za priče Mačka i Pas. 
Duljina sintaktičkih jedinica varirala je od 6 do 23 riječi, a određene su riječi spojene i prikazane jednim simbolom (priložne oznake vremena - jednog je dana, u to vrijeme, na kraju; pomoćni glagoli i povratne zamjenice s punoznačnom riječi - leptir je, ozlijedila se; veznici - kad je vidio, i pomislila; te prijedlozi u prijedložnim konstrukcijama $-u$ vodu, iz ruku, u grm). Povezivanje riječi temeljilo se na naglasnim cjelinama, a njime su izbjegnuti problemi s reprezentacijom apstraktnih riječi kao što su veznici i prijedlozi.

\section{Postupak ispitivanja}

Ispitivanje je provedeno pojedinačno sa svakim djetetom, u odvojenoj prostoriji unutar vrtićkog prostora, u trajanju od 10 do 15 minuta. Svako dijete ispitano je korištenjem jedne standardne i jedne prilagođene slikovnice. Ispitivanje se sastojalo od čitanja slikovnice i pripovijedanja djeteta uz slikovni materijal. Polovini je pročitana prilagođena verzija priče Mačka, a drugoj polovini Pas. Najprije je prikazana standardna slikovnica, a potom prilagođena. $U$ objema se pričama nakon poslušane priče od djeteta tražilo samostalno pripovijedanje te je pitanjima provjereno razumijevanje. Prilikom pričanja, ispitivač je gestom pokazivanja usmjeravao pažnju ispitanika na popratne grafičke simbole i okretao stranice. Tijekom prepričavanja i postavljanja pitanja za razumijevanje grafički simboli nisu bili vidljivi. Ispitivanja su tonski snimljena te transkribirana i analizirana prema uputama instrumenta MAIN - hrvatska inačica: Višejezični instrument za ispitivanje pripovijedanja.

\section{Obrada podataka}

Prikupljeni podatci obrađeni su statističkim programom IBM SPSS Statistics 25. Za obradu rezultata koristila se deskriptivna ana- liza te postupci inferencijalne statistike. $\mathrm{Na}$ svakoj je varijabli provjerena distribucija rezultata Kolmogorov-Smirnovljevim testom te su ovisno o rezultatima odabrani parametrijski ili neparametrijski postupci. Kako bi se utvrdila pouzdanost rezultata, ispitano je slaganje među procjenjivačima Cohenovim kappa koeficijentom. Drugi procjenjivač vrednovao je $20 \%$ uzorka. Cohenov kappa koeficijent iznosio je $0,7-1$, što odgovara umjerenoj do visokoj pouzdanosti među procjenjivačima.

\section{Rezultati i rasprava}

\section{Struktura priče}

Prilikom analize transkribiranih pripovjednih dijelova prema modelu gramatike priče bodovali su se vrijeme i mjesto radnje (2 boda) te elementi svake od triju epizoda (cilj, pokušaj, ishod, unutarnje stanje kao uvodni događaj i unutarnje stanje kao reakcija; 5 bodova po epizodi). Maksimalan broj bodova iznosio je 17.

Iako je veći prosječan broj bodova dobiven u prepričavanju nakon čitanja prilagođene slikovnice u odnosu na prepričavanje nakon standardne slikovnice, t-test za zavisne uzorke potvrdio je kako razlika nije statistički značajna $(t=1,332, d f=29, \mathrm{p}>0.05$; Tablica 1$)$.

Rezultat se može objasniti time da su djeca predškolske dobi prilikom prepričavanja na temelju standardne slikovnice već ostvarila najbolje rezultate s obzirom na svoje sposobnosti i očekivanja s obzirom na kronološku dob, dok dodatna vizualna podrška pružena putem grafičkih simbola nije bila dostatna da dovede do značajnog poboljšanja. Rezultati se podudaraju s istraživanjem Trabassa i Nickelsa (1992), koji su zaključili da u godini prije polaska u školu djeca urednog razvoja označavaju elemente priče prema modelu. 
Rosandić, M., Alviž, S., Ivšac Pavliša, J., Uloga prilagođene slikovnice u poticanju pripovijedanja Klinička psihologija 13 (2020), 1-2, 21-34

Tablica 1. Podatci deskriptivne statistike i t-test za zavisne uzorke na varijabli Struktura priče

\begin{tabular}{lrr}
\hline Struktura priče & $M(S D)$ & t-test za zavisne uzorke \\
\hline prilagođena slikovnica & $10,13(2,03)$ & 1,$332 ; d f=29 ; p=0,193$ \\
standardna slikovnica & $9,57(1,74)$ & \\
\hline
\end{tabular}

Drugo moguće objašnjenje odnosi se na vrstu prilagodbe slikovnice. Naime, slikovnica je prilagođena prvenstveno uvođenjem grafičkih simbola na razini jezičnih jedinica, dok strukturalne prilagodbe nije bilo. Moguće je da bi se više elemenata priče pojavilo kada bi se vizualnom podrškom zasebno naglasili elementi svakog dijela pojedine epizode, tj. kad bi vizualna podrška bila usmjerena na makrostrukturalne elemente, a ne mikrostrukturalne.

\section{Strukturalna složenost priče}

U okviru instrumenta MAIN ispitanikovo usložnjavanje strukture priče ocjenjuje se na temelju stabla dvostrukog odlučivanja (engl. binary decision tree) (Westby, 2005), što čini, od jednostavnijih prema složenijima, sljedeće razine složenosti: pokušaj-ishod, cilj, cilj-pokušaj, cilj-ishod i cilj-pokušaj-ishod. Nakon transkripcije pripovjednog uzorka, unutar svake epizode označena je najviša ostvarena razina strukturalne složenosti. Svaki sudionik mogao je ukupno dobiti 3 boda po epizodi, a ocjenjivala se svaka razina posebno.

Na Slici 1 prikazane su frekvencije razina složenosti s obzirom na vrstu slikovnice. $\mathrm{Na}$ najvišoj razini cilj-pokušaj-ishod ispitanici su postigli jednaku frekvenciju nakon čitanja prilagođene i standardne slikovnice. Veća frekvencija označenih razina složenosti nalazi se

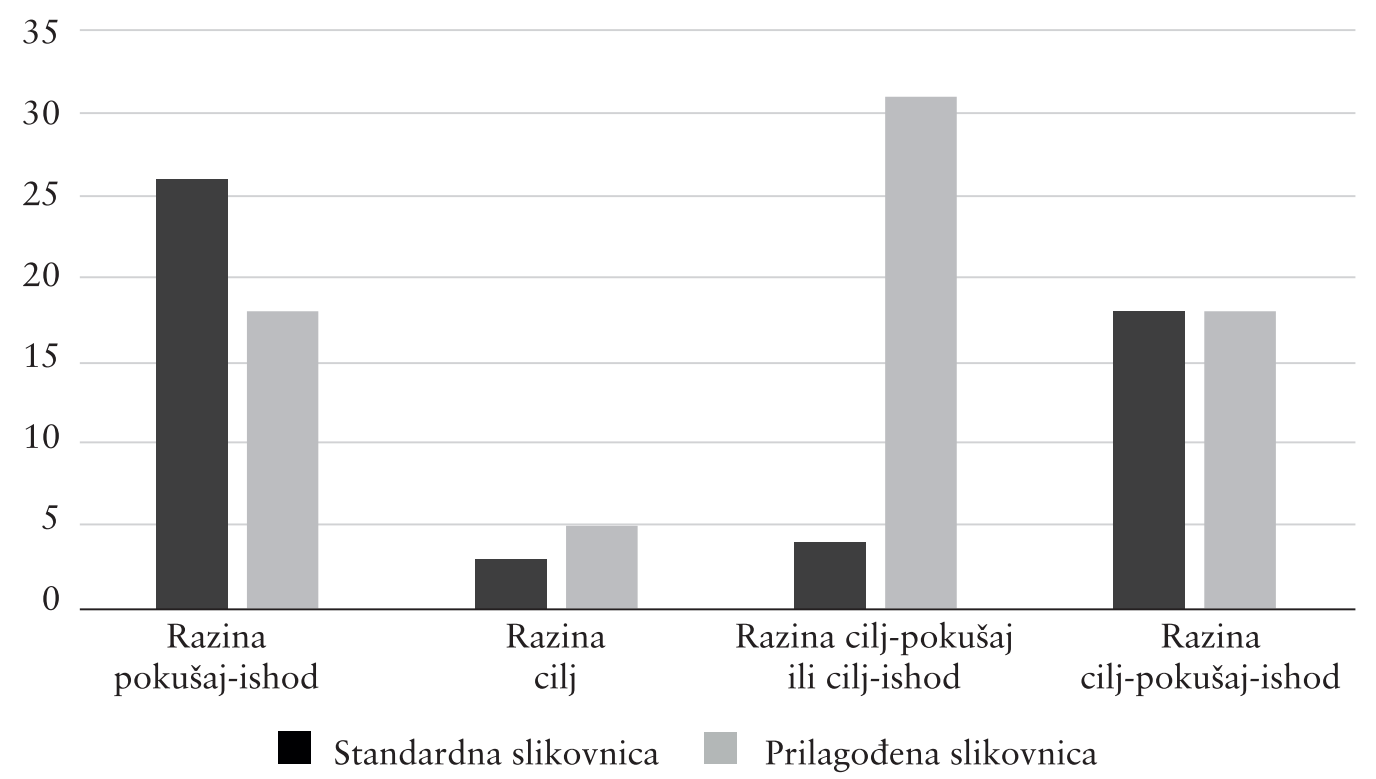

Slika 1. Frekvencija razina strukturalne složenosti pripovijedanja 
Tablica 2. Podatci deskriptivne statistike i Wilcoxonov test ekvivalentnih parova na varijabli Strukturalna složenost

\begin{tabular}{llrr}
\hline Razina složenosti & Tip slikovnice & $\mathrm{C}(\mathrm{Q})$ & $\begin{array}{l}\text { Wilcoxonov test } \\
\text { ekvivalentnih parova }\end{array}$ \\
\hline pokušaj-ishod & prilagođena slikovnica & $0,0(0,5)$ & $-1,325 ; \mathrm{p}=0,185$ \\
& standardne slikovnice & $1,00(0,625)$ & \\
\hline cilj & prilagođena slikovnica & $0,0(0,0)$ & $-0,707 ; \mathrm{p}=0,480$ \\
& standardne slikovnice & $0,0(0,0)$ & \\
\hline cilj-pokušaj ili cilj-ishod & prilagođena slikovnica & $1,00(1,0)$ & 2,$304 ; \mathrm{p}=0,021^{*}$ \\
& standardne slikovnice & $0,50(0,5)$ & \\
\hline broj cilj-pokušaj-ishod & prilagođena slikovnica & $0,0(0,5)$ & $-0,127 ; \mathrm{p}=0,899$ \\
& standardne slikovnice & $1,00(0,5)$ & \\
\hline
\end{tabular}

na razini cilj-pokušaj ili cilj-ishod i razini cilj nakon čitanja prilagođene slikovnice. Jedino na najnižoj razini pokušaj-ishod ispitanici nakon čitanja standardne slikovnice postižu veću frekvenciju. Kad se gleda općenito broj označenih razina, veća frekvencija se nalazi kod ispitanika nakon čitanja prilagođene slikovnice (72) nego nakon čitanja standardne slikovnice (64).

Kako bi se ispitala razlika među pojedinima razinama strukturalne složenosti nakon čitanja prilagođene i standardne slikovnice, proveden je Wilcoxonov test ekvivalentnih parova. Rezultati su pokazali kako postoji razlika jedino na razini cilj-pokušaj ili cilj-ishod $\mathrm{u}$ korist čitanja prilagođene slikovnice $(\mathrm{Z}=$ 2,304; $\mathrm{p}<0,05)$. Time se djelomično potvrđuje kako vizualna podrška pospješuje prepričavanje priče.

Takav zaključak u skladu je s već spomenutim dodatnim učinkom (Cheetham, 2017) koji nastaje kada se unos informacija obavlja pomoću više modaliteta. U ovom slučaju, osim auditivnog modaliteta kojim su sudionici „primili“ tekst priče i vizualnog koji prati općenitu radnju priče, u slikovnicu su uneseni i dodatni grafički simboli za podršku izgovorenom tekstu. Kako su simbolima prikazane ključne riječi za označavanje elemenata struk- ture, moguće je da su te vizualizirane riječi pridonijele konkretizaciji pripovijedanja (Takacs i Bus, 2018) te dovele do usložnjavanja priče.

\section{Označavanje unutarnjih stanja}

Riječi koje izražavaju unutarnja stanja su riječi koje označavaju različita mentalna stanja, emocije i namjere kod subjekata u priči. Kod instrumenta MAIN proučavaju se kroz strukturu priče kao element koji pokreće radnju i element koji predstavlja reakciju na ishod te kao izdvojena varijabla koja označava pojavnost takvih riječi u ukupnom pripovjednom uzorku djeteta. Stoga je tekst slikovnica ujednačen na način da sadrži jednake riječi koje izražavaju unutarnja stanja te jednak ukupan broj riječi.

Rezultati deskriptivne analize pokazali su kako se veća aritmetička sredina nalazi kod riječi koje izražavaju unutarnja stanja nakon čitanja prilagođene slikovnice nego kod standardne slikovnice $(\mathrm{M}=5,73$; $\mathrm{SD}$ $=0,74)$. To bi značilo da bolje rezultate postiže skupina djece urednog razvoja nakon čitanja prilagođene slikovnice (Tablica 3). T-test za zavisne uzorke potvrdio je značajnost navedene razlike, što upućuje na to da nakon čitanja prilagođene slikovnice sudio- 
Rosandić, M., Alviž, S., Ivšac Pavliša, J., Uloga prilagođene slikovnice u poticanju pripovijedanja Klinička psihologija 13 (2020), 1-2, 21-34

Tablica 3. Podatci deskriptivne statistike i t-test za zavisne uzorke na varijabli Označavanje unutarnjih stanja

\begin{tabular}{lcc}
\hline Označavanje unutarnjih stanja & $M(S D)$ & t-test za zavisne uzorke \\
\hline prilagođena slikovnica & $5,73(0,74)$ & \multirow{2}{*}{$t=-2,567, p=0,016^{*}$} \\
standardna slikovnica & $5,40(1,00)$ & \\
\hline
\end{tabular}

nici koriste više riječi za označavanje unutarnjih stanja nego nakon standardne slikovnice $(\mathrm{t}=-2,567 ; \mathrm{p}<0,05)$.

Riječi koje izražavaju unutarnja stanja $\mathrm{u}$ pripovjednom uzorku izvor su informacija o stupnju razvoja teorije uma kod djeteta. Točnije, otkrivaju koliko dobro dijete može razumjeti emocije protagonista, koliko ima razvijene kognitivne procese za interpretaciju ciljeva i namjera protagonista te kakva je djetetova sposobnost zaključivanja o dijelovima priče. Osim toga, prema Curenton i Justice (2004) korištenje takvih riječi je osnova pripovijedanja koje se razvija u školskom periodu i općenito je važno za akademski uspjeh. Hedberg i Stoel-Gammon (1986) navode kako se, prema elementima organizacije pripovjednog teksta koje je predložio Applebee 1978. godine, označavanje unutarnjih stanja pojavljuje tek kod pravog pripovijedanja u dobi od oko šest godina. Češća uporaba riječi za označavanje unutarnjih stanja nakon čitanja prilagođene slikovnice mogla bi potvrđivati da grafički simboli podupiru ne samo razumijevanje radnje već i razvoj teorije uma, zbog čega se učestalo koriste kao dio podrške djeci sa PSA-om.

\section{Razumijevanje sadržaja priče}

Nakon prepričavanja svake od priča pitanjima je provjereno njihovo razumijevanje. Pitanja su se postavljala uz pokazivanje na slikovni materijal gestom pokazivanja prema uputama instrumenta MAIN. Ukupno je bilo 10 pitanja na kojima su ispitanici mogli postići maksimalno 10 bodova.

Deskriptivnom analizom utvrđen je veći broj bodova nakon čitanja prilagođene slikovnice (Tablica 4), što upućuje na bolje razumijevanje priče iz prilagođene slikovnice nego standardne. Navedeno je potvrđeno Wilcoxonovim testom ekvivalentnih parova $(\mathrm{Z}=$ $-2,812 ; \mathrm{p}<0,05)$.

Iako se prilikom analize uzimao ukupan rezultat ispitanika, pitanja se mogu grupirati $\mathrm{u}$ tri kategorije. Tri su pitanja usmjerena na cilj epizode (primjer: Zašto je pas skočio?), šest pitanja na unutarnja stanja protagonista (primjer: Kako se pas osjeća?) i jedno je pitanje usmjereno na zaključivanje, tj. teoriju uma (Hoće li dječak i pas/mačka postati prijatelii? Zašto?). Na Slici 2 prikazane su frekvencije točno odgovorenih pitanja. Veći broj točnih pitanja usmjerenih na razumijevanje cilja i unutarnjih stanja zamijećen je kod prilagođene slikovnice.

Tablica 4. Podatci deskriptivne statistike i Wilcoxonov test ekvivalentnih parova Razumijevanje sadržaja

\begin{tabular}{lcc}
\hline Razumijevanje sadržaja & $\mathrm{C}(\mathrm{Q})$ & Wilcoxonov test ekvivalentnih parova \\
\hline prilagođena slikovnica & $9,0(0,0)$ & $-2,812 ; \mathrm{p}=0,005^{*}$ \\
standardna slikovnica & $9,0(0,5)$ & \\
\hline
\end{tabular}




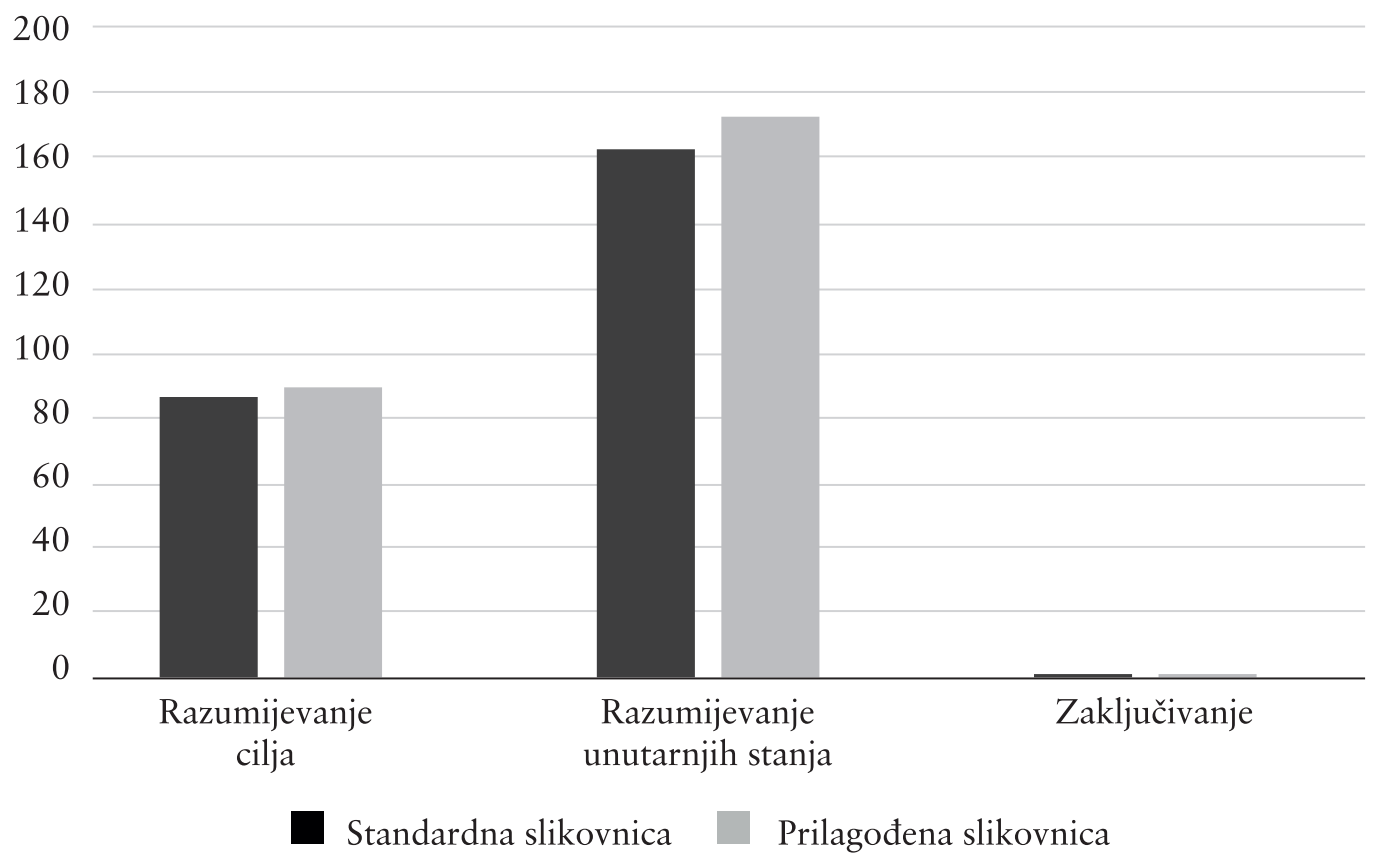

Slika 2. Frekvencija tipova točnih odgovara

Radi dodatne analize proveden je Wilcoxonov test ekvivalentnih parova, kojim su ispitane razlike u točnosti odgovora prema tipovima pitanja. Potvrđeno je kako postoji značajna razlika na pitanjima usmjerenima na razumijevanje unutarnjih stanja $(Z=-2,812$; $\mathrm{p}<$ $0,05)$ u korist čitanja prilagođenih slikovnica. Izneseni rezultati argument su za prihvaćanje pretpostavke da čitanje prilagođene slikovnice dovodi do boljeg razumijevanja sadržaja priče. Sveukupno gledajući, sudionici su točno odgovorili na preko $80 \%$ pitanja. Ipak, rezultati upućuju na pozitivne učinke vizualne podrške za pružanja informacija, što potvrđuju i rezultati inozemnih istraživanja pronađeni kod Thomas i Ross (2017), u čijem je istraživanju dobiveno poboljšanje u razumijevanju sadržaja i razine pismenosti nakon intervencije s prilagođenim slikovnicama.

\section{Zaključak}

Iako je uloga prilagođenih slikovnica u poticanju pripovjednih vještina i jezičnih sposobnosti zastupljena kao tema u istraživačkim korpusima, nije pronađen nijedan objavljeni rad u kojem se koristi instrument MAIN za ispitivanje strukturalnih sastavnica, uporabe određenih vrsta riječi te razumijevanja pripovjednih uzoraka nakon čitanja prilagođene slikovnice. Rezultati ovog rada u tom su smislu vrijedan doprinos korpusu podataka o ulozi prilagođene slikovnice (primjenom vizualne podrške u vidu grafičkih simbola) u poticanju pripovjednih sposobnosti. Izneseni rezultati pokazuju kako nakon čitanja prilagođene slikovnice dolazi do veće zasićenosti pripovjednog uzorka riječima za izražavanje unutarnjih stanja. Unatoč tome što djeca tipičnog razvoja dobro razumiju priču te prosječno netočno 
Rosandić, M., Alviž, S., Ivšac Pavliša, J., Uloga prilagođene slikovnice u poticanju pripovijedanja Klinička psihologija 13 (2020), 1-2, 21-34

odgovaraju na samo jedno od deset pitanja, pokazalo se kako nakon čitanja prilagođene slikovnice dolazi do još boljeg razumijevanja.

Dobiveni rezultati upućuju na potrebu za daljnjim istraživanjima u području uloge prilagođenih slikovnica u uspješnosti pripovijedanja. Buduća istraživanja, s bolje opisanim uzorkom sudionika te ojačavanjem metodološkog nacrta u obliku provedbe eksperimentalnog nacrta, omogućila bi snažnije zaključke o utjecaju prilagođene slikovnice na pripovjedne sposobnosti. Kako se dobiveni rezultati odnose isključivo na tipičnu populaciju, zaključke rada nije moguće generalizirati na različite kliničke populacije. Stoga bi dodatno trebalo provjeriti oslanja li se populacija s teškoćama poput razvojnog jezičnog poremećaja ili neka od skupina djece sa složenim komunikacijskim potrebama u prepričavanju priče još više na grafičke simbole.

Budući da su prilagodbe slikovnica primjenjive u logopedskoj podršci i mogu se prilagođavati u odnosu na individualna obilježja korisnika, njihova je uporaba moguća kod gotovo svake populacije kojoj je potrebno poticanje komunikacijskog i jezičnog razvoja. Upravo zbog slobode u kreiranju prilagodbi, cilj čitanja prilagođenih slikovnica mogu biti ne samo pripovjedne sposobnosti, već upoznavanje s određenim jezičnim strukturama, novim rječnikom, poticanje prosocijalnih ponašanja, povezivanje grafičkih simbola s konceptom, proširivanje komunikacijskih funkcija i sl. Kako je čitanje slikovnica aktivnost koja se nerijetko provodi u obiteljskom okruženju, velika je vjerojatnost da će roditelji djece s teškoćama spremno prihvatiti ovu prirodnu metodu poticanja komunikacijsko-jezičnog razvoja. Ulogu prilagođenih slikovnica u poticanju pripovjednih i jezičnih sposobnosti potrebno je i dalje istraživati, no sadašnje spoznaje već pružaju dovoljno argumenata za uključivanje u logopedski rad prema individualnim mogućnostima i potrebama korisnika.

\section{Literatura}

Adams, C. (2002). Practitioner Review: The assesment of language pragmatics. Journal of Child Psychology and Psychiatry, 43 (8), 973-987.

Bellon, M. L., Ogletree, B. T. i Harn, W. E. (2000). Repeated Storybook Reading as a Language Intervention for Children with Autism: A Case Study on the Application of Scaffolding. Focus on autism and other developmental disabilities, 15(1), 52-58. DOI: 10.1177/108835760001500107

Beukelman, D. R. i Mirenda, P. (2013). Augmentative and alternative communication: Supporting children and adults with complex communication needs. Baltimore, MD: Brooke.

Boerma, T., Leseman, P., Timmermeister, M., Wijnen, F. i Blom, E. (2016). Narrative abilities of monolingual and bilingual children wit and without language impairment: implications for clinical practice. International Journal of Language and Communication Disorders, 51(6), 626-638.

Browder, D. M., Mims, P. J., Spooner, F., AhlgrimDelzell, L. i Lee, A. (2008). Teaching Elementary Students With Multiple Disabilities to Participate in Shared Stories. Research and Practice for Persons with Severe Disabilities, 33 (1), 3-12. DOI: 10.2511/rpsd.33.1-2.3

Cannizzaro, M. i Coelho, C. (2013). Analysis of narrative discourse structure as an ecologically relevant measure of executive function in adults. Journal of Psycholinguistic Research, 42, 527-549. DOI: 10.1007/s10936-0129231-5

Car, Ž., Ivšac Pavliša, J. i Rašan, I. (2018). Digitalna tehnologija za potporu posebnim odgojno-obrazovnim potrebama. Zagreb: Hrvatska akademska i istraživačka mreža - CARNET.

CAST (2011). Universal Design for Learning Guidelines version 2.0. Wakefield, MA: Author.

Cheetham, D. (2017). Multi-modal language input: A learned superadditive effect. Applied Linguistics Review. DOI: 10.1515/applirev-2017-0036

Crowe, L. K., Norris, J. A. i Hoffman, P. R. (2004). Training caregivers to facilitate communicative participation of preschool children with language impairment during storybook reading. 
Journal of Communication Disorders, 37, 177196. DOI: $10.1016 /$ j.jcomdis.2003.09.001

Curenton, S. M. i Justice, L. M. (2004). African American and Caucasian Preschoolers' Use of Decontextualized Language: Literate Language Features in Oral Narratives. Language, speech, and hearing services in schools, 35(3), 240253. DOI: 10.1044/0161-1461(2004/023)

Daly, E. J., Neugebauer, S., Chafouleas, S. M. i Skinner, C. H. (2015). Interventions for reading problems: Designing and evaluating effective strategies. New York: Guilford Publications.

Dodd, J. L. (2012). Adapted Stories: Creating Accessible Stories for Children With Complex Language Problems. Special Interest Group 1 Perspectives on Language Learning and Education, 19(4), 139-146. DOI: 10.1044/ lle19.4.139

Franke, L. K. i Dodd, J. L. (2009). Impact of story complexity on story comprehension and retell skills of children with complicated language problems. American Speech-Language-Hearing Association Annual Convention. New Orleans, LA: Chapman University. DOI: 10.1044/ lle19.4.139

Gagarina, N., Klop, D., Kunnari, S., Tantele, K., Välimaa, T., Balčiūnienè, I., Bohnacker, U. i Walters, J. (2012). MAIN: Multilingual Assessment Instrument for Narratives. ZAS Papers in Linguistics, 56, 1-135.

Gillam, S.L., Gillam, R.B. (2016) Narrative Discourse Intervention for School-Aged Children with Language Impairment Supporting Knowledge in Language and Literacy. Topics in Language Disorders, 36(1), 20-34.

Golloher, A.N. (2018). Adapted Shared Storybook Reading: A Study of Its Application for Children With Autism Spectrum Disorders in Home Settings. Focus on Autism and Other Developmental Disabilities, 33(1), 35-46. DOI: $10.1177 / 1088357616681281$

Hedberg, N. L. i Stoel-Gammon, C. (1986). Narrative analysis. Topics in Language Disorders, 7(1), 58-69.

Hržica, G. i Kuvač Kraljević, J. (2012). MAIN - hrvatska inačica: Višejezični instrument za ispitivanje pripovijedanja. ZAS Papers in Linguistics 56.
Kelić, M., Hržica, G. i Kuvač Kraljević, J. (2012). Mjere jezičnog razvoja kao pokazatelji posebnih jezičnih teškoća. Hrvatska revija za rehabilitacijska istraživanja, 48(2), 23-40.

Kuvač, J. (2004). Jezik i spoznaja u ranom dječjem pripovijedanju. Magistarski rad. Zagreb: Filozofski fakultet Sveučilišta u Zagrebu.

Kuvač, J. i Palmović, M. (2007). Metodologija istraživanja dječjeg jezika. Jastrebarsko/Zagreb: Naklada Slap.

Kuvač Kraljević, J. i Olujić, M. (2015): Kasni jezični razvoj. U: Kuvač Kraljević, J. (ur): Priručnik za prepoznavanje i obrazovanje djece s jezičnim teškoćama (str. 35-49). Zagreb: Edukacijskorehabilitacijski fakultet.

Liboiron, N. i Soto, G. (2006). Shared storybook reading with a student who uses alternative and augmentative communication: A description of scaffolding practices. Child Language Teaching and Therapy, 22(1), 69-95. DOI: $10.1191 / 0265659006 \mathrm{ct} 298$ oa

Liles, B. Z., Duffy, R. J., Merrit, D. D. i Purcel, S. L. (1995). Measurement of narrative discourse ability in children with language disorders. Journal of Speech and Hearing Research, 38, 415-425.

Norbury, C. F. i Bishop, D. V. (2003). Narrative skills of children with communication impairments. International Journal of Language \& Communication Disorders, 38(3), 287-313.

Peretić, M., Padovan, N. i Kologranić Belić, L. (2015): Rana pismenost. U: Kuvač Kraljević, J. (ur): Priručnik za prepoznavanje $i$ obrazovanje djece s jezičnim teškoćama (str. 52-32). Zagreb: Edukacijsko-rehabilitacijski fakultet.

Schoonover, J. i Norton-Darr, S. (2016). Adapting books: Ready, set, read! Journal of Occupational Therapy, Schools and Early Intervention, 9(1), 19-26.

Stephenson, J. (2009). Picture-Book Reading as an Intervention to Teach the Use of Line Drawings for Communication with Students with Severe Intellectual Disabilities. Augmentative and Alternative Communication, 25(3), 202214. DOI: $10.1080 / 07434610903031216$

Takacs, Z. K. i Bus, A. G. (2018). How pictures in picture storybooks support young children's story comprehension: An eye-tracking experiment. Journal of Experimental 
Child Psychology, 174, 1-12. DOI: 10.1016/j. jecp.2018.04.013

Thomas, D. i Ross, B. (2017). Promoting Reading Success: The Effects of an Adapted Book on Reading Comprehension. Journal of Communication Disorders and Assistive Technology, 1, 1-11.

Trabasso, T. i Nickels, M. (1992). The development of goal plans of action in the narration of a picture story. Discourse Processes, 15 (3), 249275. DOI: $10.1080 / 01638539209544812$

Trudeau, N., Cleave, P. L. i Woelk., E. J. (2003). Using augmentative and alternative communi- cation approaches to promote participation of preschoolers during book reading: a pilot study. Child Language Teaching and Therapy, 19, 181-210. DOI: 10.1191/0265659003ct250oa

Vygotsky, L. S. (1986). Thought and language - Revised edition. Cambridge, MA: Massachusetts Institute of Technology.

Westby, C. E. (2005). Assessing and facilitating text comprehension problems. U: H. Catts i A. Kamhi (ur.), Language and reading disabilities (157-232). Boston; MA: Allyn \& Bacon.
Korespondencija: Monika Rosandić

Edukacijsko-rehabilitacijski fakultet Sveučilišta u Zagrebu, Zagreb, Hrvatska

Borongajska 83 f, 10000 Zagreb

mrosandic@erf.unizg.hr

$\begin{array}{ll}\text { Primljeno: } & \text { 29. 01.2020. } \\ \text { Prihvaćeno: } & 24.09 .2020 . \\ \text { Online: } & 30.10 .2020 . \\ \text { Print: } & \text { 27.11.2020. }\end{array}$

\section{The Role of Adapted Storybooks in Promoting Narrative Skills}

Summary: Shared storybook reading is a naturalistic activity that promotes early literacy skills and is predictive for later reading and writing. Owing to a wide variety of possibilities, like technical, content or language adaptations, these storybooks offer the opportunity of interactive participation to children with a wide variety of impairments, while also displaying beneficial effects on children with typical development. The aim of this study was to investigate the achievement of narration after reading the adapted storybook compared to reading a standard storybook. Narrative skills were analysed on the macrostructural level on a sample of 30 children aged from 5;07 to 6;07 years. Their cognitive and language development was typical. Two stories, Mačka and Pas, were used which are part of MAIN - Croatian version: Multilingual Assessment Instrument for Narratives.

The results indicated that after reading adapted storybooks, children have significantly differed in the area of comprehension and in using words that indicate internal states of characters. No significant difference was found in the general structure of the story and on most of the levels of structural complexity. These results point to the need for further research in this area in order to establish the ground of evidence based speech and language practice.

Keywords: adapted storybook, narrative skills, complex communication needs, MAIN-Croatian version: Multilingual Assessment Instrument for Narratives 
